\title{
Fluoride behaviour analysis in groundwater with reference to hydrogeochemical parameters in basaltic aquifers using remote sensing and GIS technique in parts of Burhner watershed, MP, India
}

\author{
Kamlesh Prasad ${ }^{1, *}$ and J P ShuKLa ${ }^{2}$ \\ ${ }^{1}$ Disaster Management Institute, Paryavaran Parisar, Bhopal 462 016, India. \\ ${ }^{2}$ Advanced Materials and Processes Research Institute, Council of Scientific and Industrial Research (CSIR), \\ Near Habibganj Naka, Hoshangabad Road, Bhopal 462 026, India. \\ *Corresponding author.e-mail: kamleshp97@gmail.com
}

MS received 24 November 2017; revised 13 May 2019; accepted 4 June 2019

High fluoride concentration in groundwater leads to health threat to millions of people around the world; therefore, a systematic study is required to understand the behaviour of fluoride in water in terms of the local hydrogeological setting and other hydrogeochemical parameters. The present study is an attempt to assess the hydrogeology of groundwater in the study area to understand the fluoride behaviour in groundwater and to deduce the chemical parameters responsible for the dissolution activity of fluoride. $\mathrm{F}^{-}$value varies from 0.04 to $14.6 \mathrm{mg} / \mathrm{l}$ (mean: $3.15 \mathrm{mg} / \mathrm{l}$ ) in the stuldy area. It is geologically occupied by basalt rocks where groundwater occurs in the weathered and fractured portions of the rocks and under semi-confined to confined conditions in fractured rocks. High $\mathrm{F}^{-}$concentration is observed in deeper aquifers compared to shallow aquifers. Physicochemical conditions like decomposition, dissociation and subsequent dissolution along with long residence time are responsible for leaching of $\mathrm{F}^{-}$into the groundwater. $\mathrm{F}^{-}$has +ve or -ve correlation with other parameters of water samples as per their nature. Simple to compound pahoehoe basaltic lava flows are responsible for the fluoride contamination in the confined aquifers (bore wells) of the study area. Overall confined aquifer water quality on the basis of fluoride concentration was found to be unsatisfactory for drinking purposes. About $57.13 \%$ of confined aquifers showed higher fluoride than the permissible limit but 100\% unconfined aquifers (dug wells) have a low level of fluoride concentration, i.e. below the permissible limit.

Keywords. Fluoride; ground water quality; Deccan basalt.

\section{Introduction}

About $96 \%$ of fluoride in the human body is found in bones and teeth. Fluoride is essential for the mineralisation of bones and the formation of the dental enamel (Park 2011). The area has long been affected with high groundwater fluoride concentration which is reported to reach up to $>18.2 \mathrm{mg} / \mathrm{l}$ in Mandla district (Chouhan et al. Published online: 08 August 2019
2008) of Madhya Pradesh, India. The main source of fluorine is from drinking water and food such as sea fish, cheese and tea (Passmore et al. 1974). Some elements are essential in trace amounts for human beings, while higher concentrations of these elements cause toxic effects, and fluoride $\left(\mathrm{F}^{-}\right)$is one of them (Technical Report, CGWB, Ministry of Water Resources, Govt. of India 1999). Concentration of fluoride between 
0.6 and $1.0 \mathrm{mg} / \mathrm{l}$ in potable water protects tooth decay and enhances bone development (Kundu et al. 2001). Indian drinking water standards have suggested (Standard Methods for the Examination of Water for Drinking Water Specification 2003) a permissible limit of $\mathrm{F}^{-}$in drinking water at $1.0 \mathrm{mg} / \mathrm{l}$, which is lower than the maximum tolerance limit $(1.5 \mathrm{mg} / \mathrm{l})$ of $\mathrm{F}^{-}$in drinking water specified by WHO guidelines for drinking water quality (WHO 1984). About 85 million tons of fluoride deposits are on the Earth's crust, 12 million tons are found in India (Teotia and Teotia 1984).

The ingestion of water with $\mathrm{F}^{-}$concentration above $1.5 \mathrm{mg} / \mathrm{l}$ results in fluorosis. The first case of fluorosis was detected in India from Andhra Pradesh during early 1930s (Shortt et al. 1937). Madhya Pradesh is one of the states affected by endemic fluorosis (Agrawal et al. 1997). Endemic fluorosis has been prevalent in India since 1973 (Shortt et al. 1937). Endemic fluorosis resulting in high fluoride concentration in groundwater is a public health problem in India (Kotecha et al. 2012). The present study is focused on the relationship between fluoride and hydrogeochemical parameters as well as with geomorphology and lithology.

\section{Study area}

The study area is bounded by latitude $22^{\circ} 33^{\prime} 00^{\prime \prime}-22^{\circ} 51^{\prime} 00^{\prime \prime} \mathrm{N}$ and longitude $80^{\circ} 31^{\prime} 00^{\prime \prime}-$ $80^{\circ} 41^{\prime} 00^{\prime \prime} \mathrm{E}$ and covers about $325 \mathrm{~km}^{2}$ of the geographical area (figure 1). The area has a semi-arid climate with a temperature of $41.3^{\circ} \mathrm{C}$ and the mean daily minimum is at $24^{\circ} \mathrm{C}$. The average annual precipitation is $1182 \mathrm{~mm}$. Sandy loam, loam and clay loam are the main soil types in the study area, which act as a natural filter to screen out many substances that mix with water.

The area is occupied by an undulating dissected plateau, with hills having an elevation of 457-680 $\mathrm{m}$ from the mean sea level (msl). River Burhner and its tributary Gurbani and Anari drain the area. The drainage pattern in the study area is sub-dendritic to dendritic. Geologically, the study area is dominated by basaltic lava flows of the Deccan volcanic province. Basaltic lava flows (Upper Cretaceous to Palaeocene) belonging to the Dhuma formations of the Amarkantak group overlie the older formations. The flows are simple 'aa' and compound 'pahoehoe' types (Report: District Resource Map 2003). Alluvium and black cotton soils overlie the basalts belonging to the Quaternary time of the geological era. Rainfall is the main source of groundwater recharge. Groundwater samples were collected under phreatic conditions in the weathered zone, fractured and vesicular basalts (shallow aquifer) and under semi-confined to confined conditions in the fractured zone (deep aquifer). The depth of the water level varies from 1.2 to $8.5 \mathrm{~m}$ below the ground level (bgl) in shallow aquifers and from 10.1 to $37.7 \mathrm{~m}$ (bgl) in the deeper aquifers. Maximum elevation in the area is $820 \mathrm{~m}$ while the minimum elevation is $460 \mathrm{~m}$ above $\mathrm{msl}$.

\section{Materials and methodology}

About 28 water samples were collected from confined aquifers and 14 from unconfined aquifers from different villages (figure 1) for a comparative study. Groundwater sampling and analysis has been carried out during the pre-monsoon of 2009. Fluoride concentration along with other chemical parameters was analysed using the standard chemical analytical techniques (Report: Standard methods for the examination of water and wastewater 1998). Fluoride was analysed by HACH DR 2010, spectrophotometer and TDS, $\mathrm{pH}$ and EC have been measured using a handheld apparatus, and the measured results are presented in table 1. Correlation matrix has been prepared using data from table 1 with the help of Microsoft Office Excel software. The analysed chemical results were used for creating Karl Pearson correlation matrix of the confined aquifers and unconfined aquifers data presented in tables 2 and 3 .

IRS P6 LISS-III remote sensing data (figure 2) have been used for preparing geomorphological maps which has been shown in figure 3 along with confined aquifer and unconfined aquifer location on different geomorphic units. Confined aquifer and unconfined aquifer location with $\mathrm{Fe}^{-}$ concentration on different lithological units is shown as figure 4 has been prepared using IRS P6 LISS-III data and the district resource map was published by the Geological Survey of India in Arc GIS software. The analysed fluoride results were created as point shape files in the Arc GIS platform and superimposed on lithological and geomorphic maps for further analysis. 


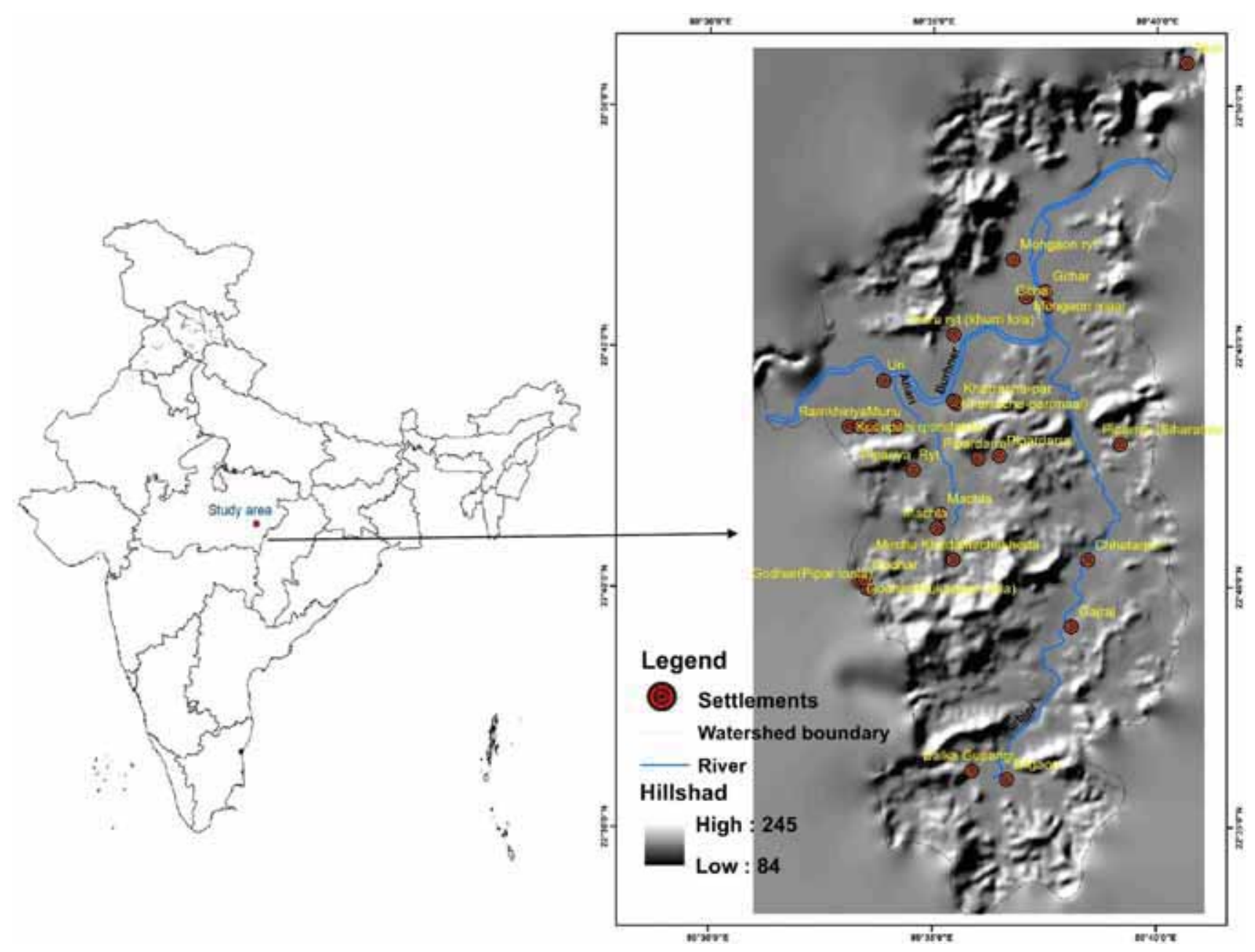

Figure 1. Location map of the study area.

\section{Results and discussions}

A comparison of the $\mathrm{F}^{-}$concentration of groundwaters at shallow aquifers $<7.5 \mathrm{~m} \mathrm{bgl}$ and deeper aquifers $>7.5 \mathrm{~m} \mathrm{bgl}$ has indicated that deeper aquifers have higher $\mathrm{F}^{-}$concentration than shallow aquifers (Standard methods for the examination of water for drinking water specification 2003). The fluoride concentration in $42.87 \%$ confined aquifers was under permissible limit $(<1.5 \mathrm{ppm})$ and $57.13 \%$ samples showed higher fluoride concentration than the permissible limit. All or $100 \%$ of unconfined aquifers showed fluoride concentration below the permissible limit. Similarly, the $\mathrm{pH}$ of groundwater from deeper aquifers is high as compared to that of the shallow aquifers.

The geomorphology, hydrogeology and geochemistry of sediments influence the occurrence, origin and mobilisation of arsenic in sedimentary aquifers (Bhattacharya et al. 1997; Kinniburgh and
Smedley 2001). Ravenscroft et al. (2001) have shown that the occurrence of arsenic has a close relationship with geomorphological units.

The flat terrain of the area with very less slope provides the surface water with these geomorphic features enough time to infiltrate deep into the aquifer, thus providing the pathway for the contaminant to reach the groundwater (Singha et al. 2014).

From the analysis of the hydrogeomorphology of the study area, groundwater is being extracted from the unconfined and confined aquifers through dug wells and tube wells, maximum groundwater elevation has taken place in the northern part of the area which is near the river valley (figure 5). As seen in hydrogeological maps, the maximum area falls in the good to the moderate unit and covers $152.59 \mathrm{~km}^{2}$ area, maximum water elevation also observed (3.7 and $3.4 \mathrm{~m}$ ), the second largest unit is moderate to poor covering 134.26 and very good to 


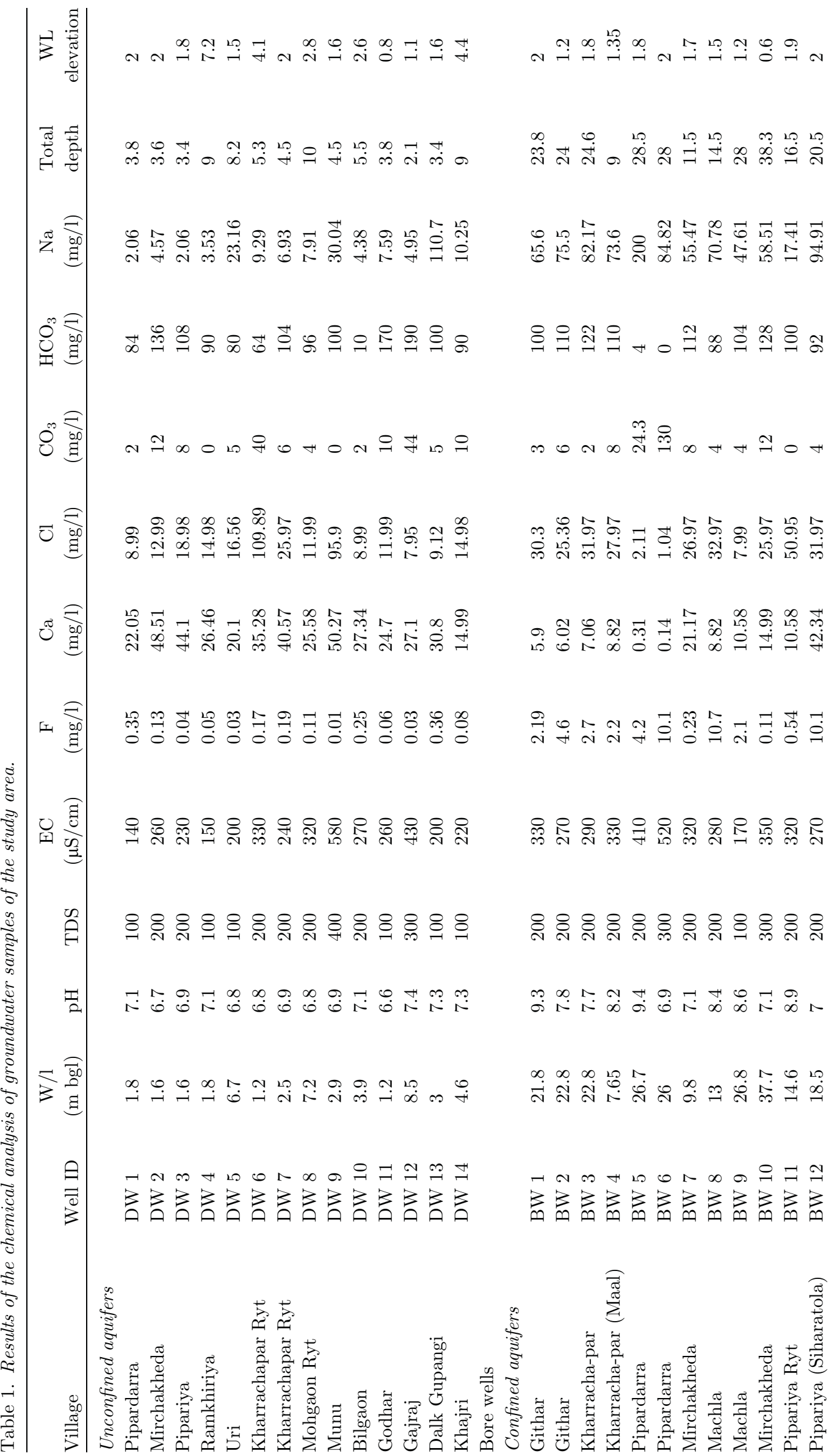




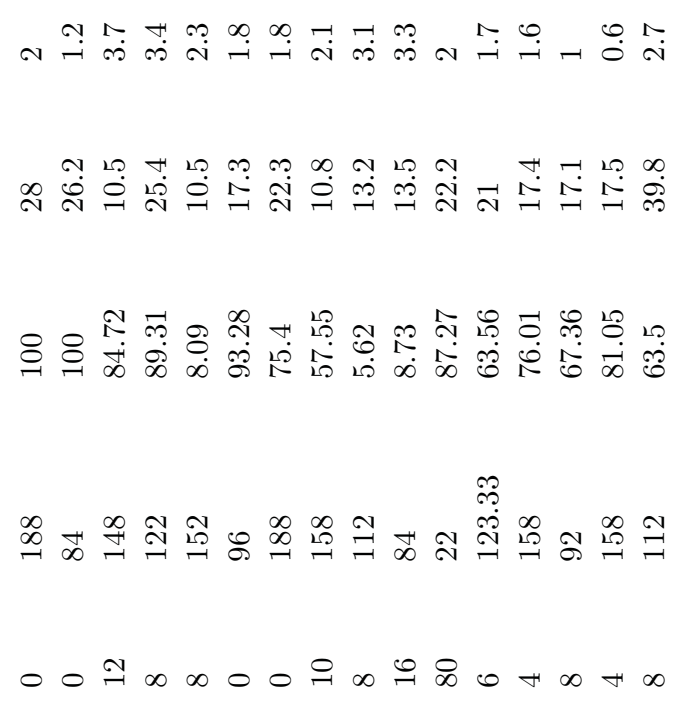

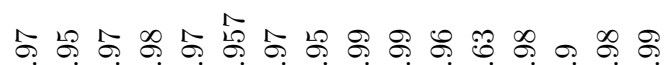

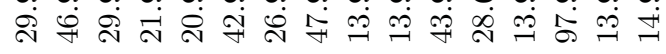

బ

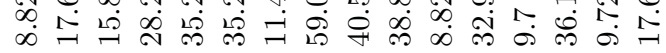

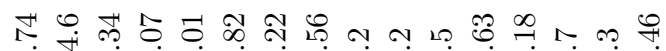
-

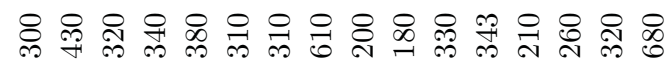

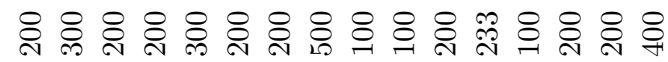

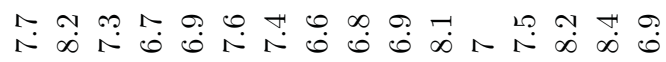

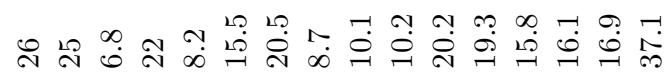

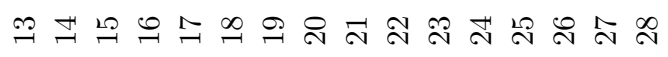

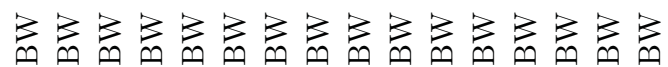

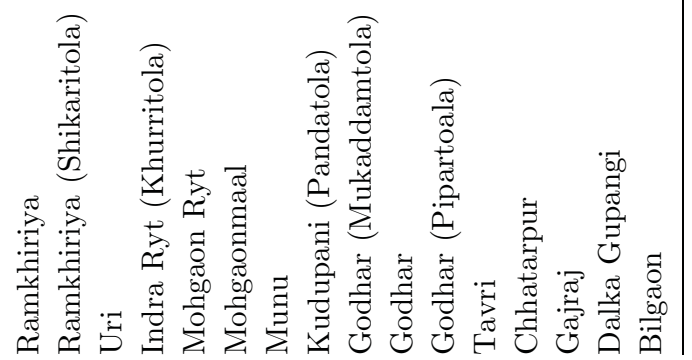

good as the unit covers $24.77 \mathrm{~km}^{2}$ area and the smallest units covered by poor to nil units is $13.38 \mathrm{~km}^{2}$ area.

The observation of a 3D model with Arcscene software with regard to the study of the water-level elevation of confined aquifers shows a maximum fluctuation of $3.6 \mathrm{~m}$ in bore well (BW) as confined aquifer 15 near the Burhner river valley at 451-505 m elevation from the mean sea level; morphologically, it is in the pediplain units and the lowest elevation of water table is found at $0.6 \mathrm{~m}$. (figure 6), whereas in unconfined aquifers, the maximum elevation of $7 \mathrm{~m}$ and minimum of $0.8 \mathrm{~m}$ were identified (figure 7 ).

Groundwater from the unconfined aquifers is slightly acidic to slightly alkaline ( $\mathrm{pH}$ 6.6-7.4), while that from confined aquifers is slightly acidic to alkaline ( $\mathrm{pH}$ 6.6-9.4; table 1). The samples have electrical conductivity (EC) values in the range of $140-580 \mu \mathrm{s} / \mathrm{cm}$ in shallow aquifers and 170-680 $\mu \mathrm{s} /$ $\mathrm{cm}$ in deeper aquifers. The average calcium $\left(\mathrm{Ca}^{2+}\right)$ concentration from shallow and deep aquifers is in the range $22.05-50.27$ and $0.14-59.05 \mathrm{mg} / \mathrm{l}$, respectively. Similarly, sodium $\left(\mathrm{Na}^{+}\right)$concentration ranges from 2.06 to 110.7 and 5.62 to $200 \mathrm{mg} / \mathrm{l}$ in shallow and deep aquifers, respectively. The concentrations of chloride $\left(\mathrm{Cl}^{-}\right)$in shallow aquifers range from 7.95 to $109.89 \mathrm{mg} / \mathrm{l}$ but in deep aquifers, it varies from 1.04 to $97.9 \mathrm{mg} / \mathrm{l}$. The $\mathrm{F}^{-}$concentration ranges from 0.01 to $0.36 \mathrm{mg} / \mathrm{l}$ in shallow aquifers (unconfined aquifers) and from 0.01 to $14.6 \mathrm{mg} / \mathrm{l}$ in confined aquifers.

From the correlation matrix (tables 2 and 3), it is found that confined aquifer water samples have a weak positive correlation between $\mathrm{pH}$ and $\mathrm{F}^{-}$ $(r=0.239)$ which suggests that $\mathrm{pH}$ is slightly important in determining $\mathrm{F}^{-}$concentration in the water from confined aquifers. The correlation of $\mathrm{F}$ with $\mathrm{CO}_{3}{ }^{-}(r=0.242)$ and $\mathrm{Na}^{+}(r=0.384)$ is also a weak positive correlation. A weak negative correlation is seen between fluoride and $\mathrm{Ca}^{2+}$ $(r=-0.219), \mathrm{HCO}_{3}^{-}(r=-0.386)$ in contrast to a significantly very weak positive correlation between fluoride and TDS $(r=0.135)$ and EC $(r=0.149)$ but no clear correlation with $\mathrm{Cl}^{-}$ $(r=0.023)$ table 2.

In the case of water from unconfined aquifers, the correlation of $\mathrm{F}^{-}$with TDS $(r=-0.355)$, EC $(r=-0.427), \mathrm{Ca}^{2+}(r=-0.122), \mathrm{Cl}^{-}(r=-0.173)$, $\mathrm{CO}_{3}{ }^{-}(r=-0.168)$ and $\mathrm{HCO}_{3}^{-}(r=-0.405)$ is weak negative while with $\mathrm{pH}(r=0.271)$ and $\mathrm{Na}^{+}$ $(r=0.429)$, it is weak positive. The result of the correlation matrix shows that EC, TDS, $\mathrm{HCO}_{3}$ and 
Table 2. Correlation matrix for different water quality parameters of confined aquifers.

\begin{tabular}{|c|c|c|c|c|c|c|c|c|c|}
\hline & $\begin{array}{c}\mathrm{F}^{-} \\
(\mathrm{mg} / \mathrm{l})\end{array}$ & $\mathrm{pH}$ & TDS & $\begin{array}{c}\mathrm{EC} \\
(\mu \mathrm{S} / \mathrm{cm})\end{array}$ & $\begin{array}{c}\mathrm{Ca} \\
(\mathrm{mg} / \mathrm{l})\end{array}$ & $\begin{array}{c}\mathrm{Cl} \\
(\mathrm{mg} / \mathrm{l})\end{array}$ & $\begin{array}{c}\mathrm{CO}_{3} \\
(\mathrm{mg} / \mathrm{l})\end{array}$ & $\begin{array}{l}\mathrm{HCO}_{3} \\
(\mathrm{mg} / \mathrm{l})\end{array}$ & $\begin{array}{c}\mathrm{Na} \\
(\mathrm{mg} / \mathrm{l})\end{array}$ \\
\hline $\mathrm{F}^{-}(\mathrm{mg} / \mathrm{l})$ & 1 & & & & & & & & \\
\hline $\mathrm{pH}$ & 0.239 & 1 & & & & & & & \\
\hline TDS & 0.135 & -0.303 & 1 & & & & & & \\
\hline $\mathrm{EC}(\mu \mathrm{S} / \mathrm{cm})$ & 0.149 & -0.218 & 0.914 & 1 & & & & & \\
\hline $\mathrm{Ca}(\mathrm{mg} / \mathrm{l})$ & -0.219 & -0.595 & 0.252 & 0.057 & 1 & & & & \\
\hline $\mathrm{Cl}(\mathrm{mg} / \mathrm{l})$ & 0.023 & 0.145 & 0.171 & -0.031 & 0.332 & 1 & & & \\
\hline $\mathrm{CO}_{3}(\mathrm{mg} / \mathrm{l})$ & 0.242 & -0.121 & 0.148 & 0.295 & -0.262 & -0.222 & 1 & & \\
\hline $\mathrm{HCO}_{3}(\mathrm{mg} / \mathrm{l})$ & -0.386 & -0.304 & 0.056 & -0.124 & 0.232 & 0.075 & -0.661 & 1 & \\
\hline $\mathrm{Na}(\mathrm{mg} / \mathrm{l})$ & 0.384 & 0.375 & 0.064 & 0.212 & -0.408 & -0.086 & 0.150 & -0.332 & 1 \\
\hline
\end{tabular}

Table 3. Correlation matrix for different water quality parameters of unconfined aquifers.

\begin{tabular}{|c|c|c|c|c|c|c|c|c|c|}
\hline & $\begin{array}{c}\mathrm{F}^{-} \\
(\mathrm{mg} / \mathrm{l})\end{array}$ & $\mathrm{pH}$ & $\begin{array}{c}\text { TDS } \\
(\mathrm{ppm})\end{array}$ & $\begin{array}{c}\mathrm{EC} \\
(\mu \mathrm{S} / \mathrm{cm})\end{array}$ & $\begin{array}{c}\mathrm{Ca} \\
(\mathrm{mg} / \mathrm{l})\end{array}$ & $\begin{array}{c}\mathrm{Cl} \\
(\mathrm{mg} / \mathrm{l}) \\
\end{array}$ & $\begin{array}{c}\mathrm{CO}_{3} \\
(\mathrm{mg} / \mathrm{l}) \\
\end{array}$ & $\begin{array}{l}\mathrm{HCO}_{3} \\
(\mathrm{mg} / \mathrm{l})\end{array}$ & $\begin{array}{c}\mathrm{Na} \\
(\mathrm{mg} / \mathrm{l}) \\
\end{array}$ \\
\hline $\mathrm{F}^{-}(\mathrm{mg} / \mathrm{l})$ & 1 & & & & & & & & \\
\hline $\mathrm{pH}$ & 0.271 & 1 & & & & & & & \\
\hline TDS (ppm) & -0.355 & -0.022 & 1 & & & & & & \\
\hline $\mathrm{EC}(\mu \mathrm{S} / \mathrm{cm})$ & -0.427 & -0.057 & 0.924 & 1 & & & & & \\
\hline $\mathrm{Ca}(\mathrm{mg} / \mathrm{l})$ & -0.122 & -0.367 & 0.653 & 0.470 & 1 & & & & \\
\hline $\mathrm{Cl}(\mathrm{mg} / \mathrm{l})$ & -0.173 & -0.278 & 0.530 & 0.598 & 0.466 & 1 & & & \\
\hline $\mathrm{CO}_{3}(\mathrm{mg} / \mathrm{l})$ & -0.168 & 0.157 & 0.272 & 0.333 & 0.002 & 0.302 & 1 & & \\
\hline $\mathrm{HCO}_{3}(\mathrm{mg} / \mathrm{l})$ & -0.405 & -0.044 & 0.159 & 0.239 & 0.120 & -0.209 & 0.393 & 1 & \\
\hline $\mathrm{Na}(\mathrm{mg} / \mathrm{l})$ & 0.429 & 0.310 & -0.132 & -0.017 & 0.032 & 0.005 & -0.158 & -0.035 & 1 \\
\hline
\end{tabular}

The results in tables 2 and 3 are based on Karl Pearson correlation analysis.

$\mathrm{CO}_{3}$ of confined aquifer water samples have shown a positive correlation which is contrast to that of the unconfined aquifer water samples.

Positive correlation between fluoride with $\mathrm{Na}$ and $\mathrm{HCO}_{3}$ in groundwater shows that the high fluoride content and alkaline sodic characteristics of groundwater result from the dissolution of fluorine-bearing minerals (Chunli et al. 2015) and negative correlation of fluoride with $\mathrm{Ca}^{2+}$ is as expected due to the low solubility of the fluorides of these ions (Handa 1975; Hem 1991; Hounslow 1995; Smedley et al. 2002; Das et al. 2003). The preferential removal of $\mathrm{Ca}^{2+}$ by several geochemical processes in aquifers, such as calcite precipitation, adsorption and cation exchange, may generate high concentrations of fluoride in groundwater and fluoride hydroxyl exchange/adsorption reaction occurs in the clay minerals with the alkaline water releasing fluoride into the groundwaters, and $\mathrm{CaF}$ solubility control and $\mathrm{OH}-\mathrm{F}$ exchange reactions, $\mathrm{F}$ can be enriched in soda water (Chunli et al. 2015).
The presence of $\mathrm{CaCO}_{3}$ favours the dissociation of $\mathrm{F}^{-}$from $\mathrm{F}^{-}$containing minerals (N. Subba Rao 2003).

In general, the aridity of climate is one of the primary reasons for the origin of high $\mathrm{F}^{-}$in groundwater. Several processes, namely the dissolution of $\mathrm{F}^{-}$bearing minerals, ion exchange and evaporative concentration can locally account for high $\mathrm{F}^{-}$concentration in groundwater (Apambire et al. 1997; Jacks et al. 1993; Agrawal et al. 1997; Saxena and Ahmed 2003).

The ions like $\mathrm{Cl}_{2}, \mathrm{~F}, \mathrm{HCO}_{3}, \mathrm{NO}_{3}$ and $\mathrm{Si}$ show an increasing trend due to the effective leaching from rock matrix along with anthropogenic activities (Srinivasamoorthy et al. 2008). Fluoride solubility in groungwater is depend on temperature and pressure (Nordstrom and Jenne 1997).

In the study area, fluoride-bearing minerals are identified as uranyl fluoride, apatite and carbonate fluorapatite (Prasad and Shukla 2014). The main sources of $\mathrm{F}^{-}$in natural water are $\mathrm{F}^{-}$bearing 


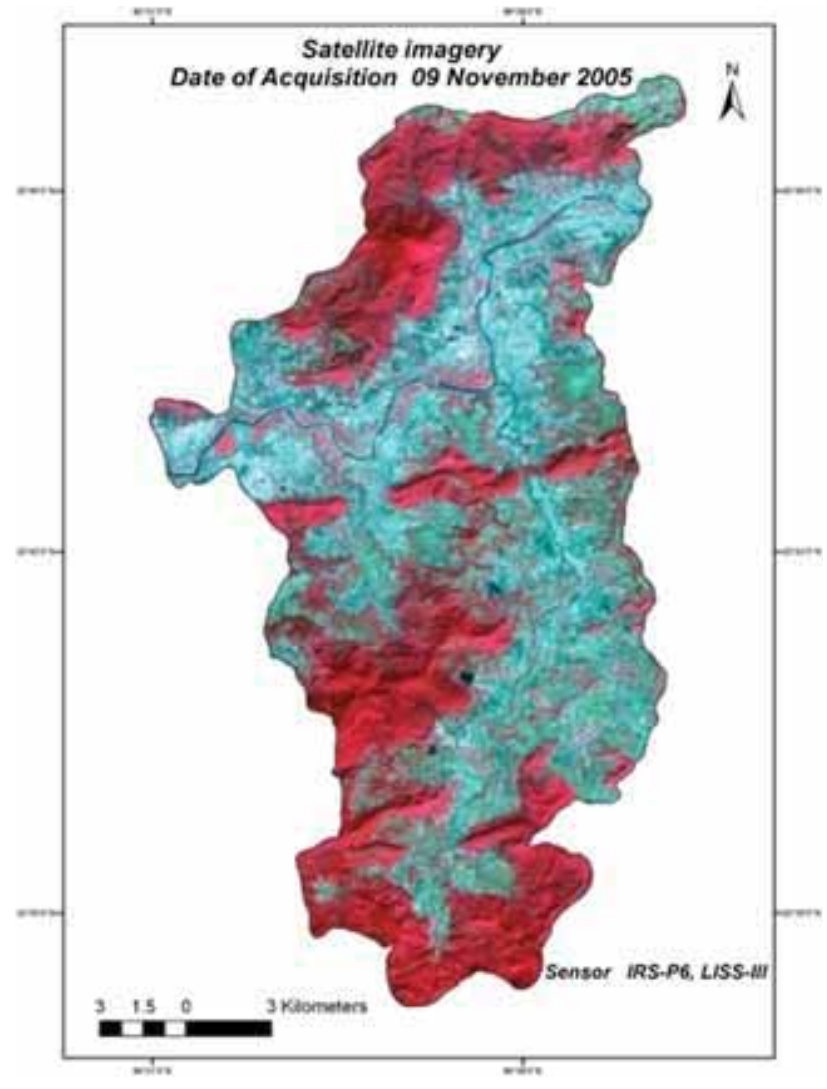

Figure 2. Remote sensing data IRS P6 LISS-III.

minerals (fluorite, fluorapatite, cryolite and apophyllite) as well as $\mathrm{F}^{-}$replacing $\mathrm{OH}^{-}$in the ferromagnesium silicates (amphiboles and micas), and soil consisting of clay minerals (Ramesam and Rajagopalan 1985; Subba Rao et al. 1998; Muralidharan et al. 2002). According to Saxena and Ahmed (2001), alkaline $\mathrm{pH}$ ranging from 7.6 to 8.6 with high and moderate EC are the favourable conditions for $\mathrm{CaF}_{2}$ dissolution in groundwater. High-fluoride-bearing groundwater is distributed mostly over arid and semi arid areas (Liu and Zhu 1991).

The confined aquifer tapping simple compound 'pahoehoe' flows have high concentration of $\mathrm{F}^{-}$ compared to unconfined aquifer tapping simple compound flows. A comparative sluggish movement of groundwater in compound 'pahoehoe' flows provided more favourable hydrogeological conditions for dissolution of $\mathrm{F}^{-}$, as these are more porous and less permeable (Technical Report 2013). The residence times of water with the aquifer materials also significantly regulate the $\mathrm{F}^{-}$ concentrations in the groundwater (Ramamohana Rao et al. 1993; Wodeyar and Srinivasan 1996; Saxena and Ahmed 2001). High concentration of $\mathrm{F}^{-}$

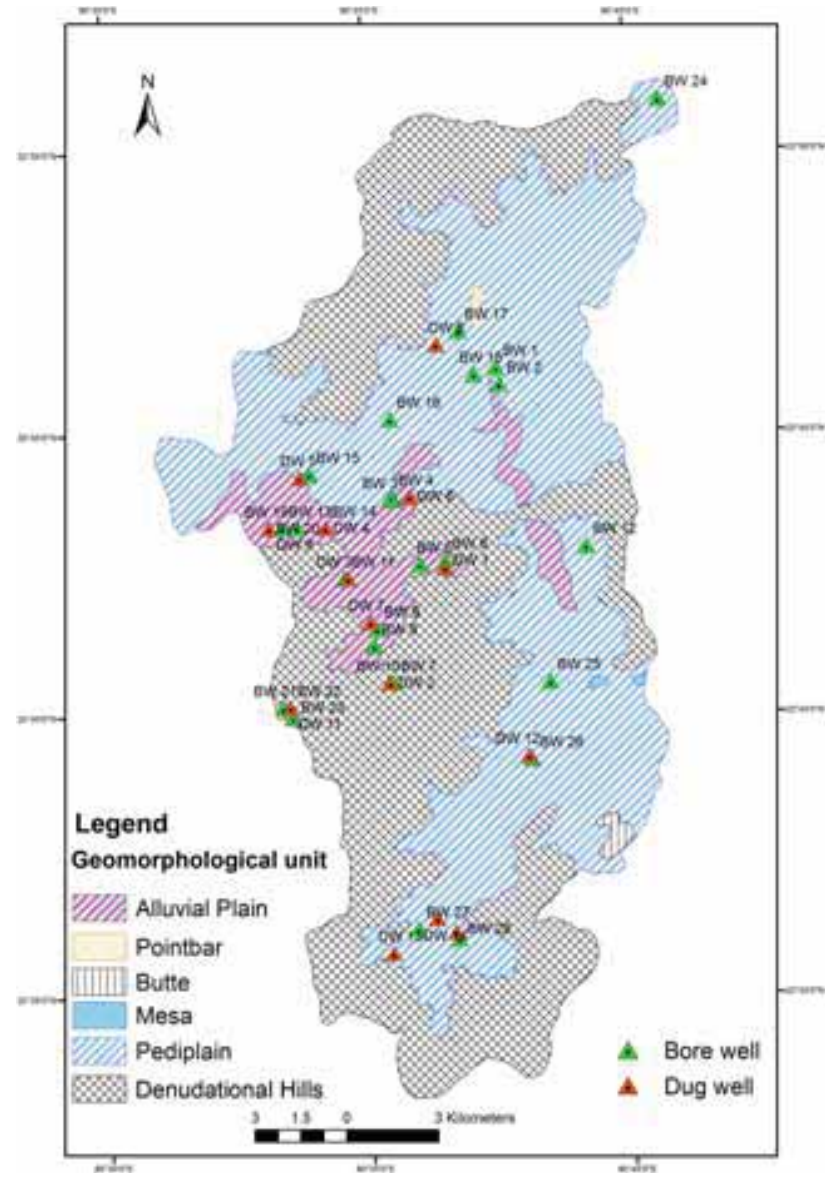

Figure 3. Confined aquifer and unconfined aquifer location on different geomorphic units.

in deeper aquifers compared to shallow aquifers could be due to its high residence time in the aquifer system, thereby having longer contact time for the dissolution of $\mathrm{F}^{-}$bearing minerals present. The present investigation on groundwater quality with reference to $\mathrm{F}^{-}$concentration in Burhner watershed indicates that the groundwater is of moderate alkaline to alkaline category and mostly brackish. Weathering and leaching of $\mathrm{F}^{-}$bearing minerals under an alkaline environment account for the enrichment of $\mathrm{F}^{-}$in groundwater.

In the study area which has 22 basaltic lava flows and spans a very vast area, $\mathrm{F}^{-}$bearing minerals are studied and identified, namely (uranyl fluoride $\left(\mathrm{UO}_{2} \mathrm{~F}_{2}\right)$, apatite $\left[\mathrm{Ca}_{5}(\mathrm{~F}, \mathrm{OH}, \mathrm{Cl})\left(\mathrm{PO}_{4}\right)_{3}\right]$, carbonate fluorapatite $\left.\left[\mathrm{Ca}_{5}\left(\mathrm{PO}_{4}, \mathrm{CO}_{3}\right)_{3} \mathrm{~F}\right]\right)$ have been identied by the XRD technique in rock samples from the drilling of selected confined aquifer were collected from different depths which express that the origin of fluoride is geogenic which is responsible for groundwater contamination (Prasad and Shukla 2014). Many researchers have reported that the source of fluoride in the groundwater of the Mandla 


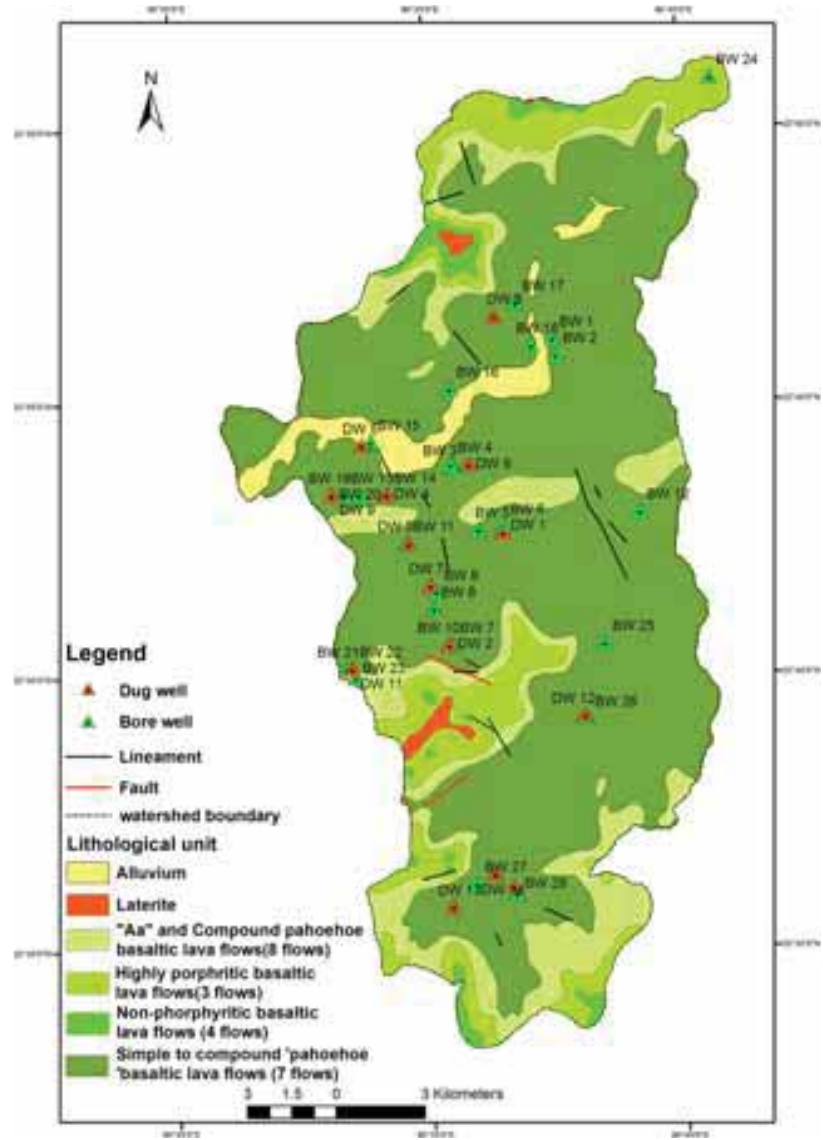

Figure 4. Confined aquifer and unconfined aquifer location with $\mathrm{F}^{-}$concentration on different lithology.

district is mainly from geological occurrence (i.e., fluoride-bearing minerals, namely, apatite and biotitic mica, fluoride are fluorite, apatite, mica, amphiboles; Purnima 2013).

Minerals like fluorspar and fluoroapatite are the main sources of fluoride in groundwater (Chouhan et al. 2008). The Central Ground Water Board, North Central Region, Bhopal 2013 also reported the geogenic problem of high concentration of fluoride in groundwater of Mandla district.

In the groundwater, major ion chemistry and possibly $\mathrm{pH}$, which are controlled by water-rock interaction processes and the geologic setting in the aquifer, are important in mobilising F (Pujari and Deshpande 2005; Farooqi et al. 2007).

The geomorphology, hydrogeology and geochemistry of sediments influence the occurrence, origin and mobilisation of arsenic in sedimentary aquifers (Bhattacharya et al. 1997; Kinniburgh and Smedley 2001). Ravenscroft et al. (2001) have shown that the occurrence of arsenic has a close relationship with geomorphological units.

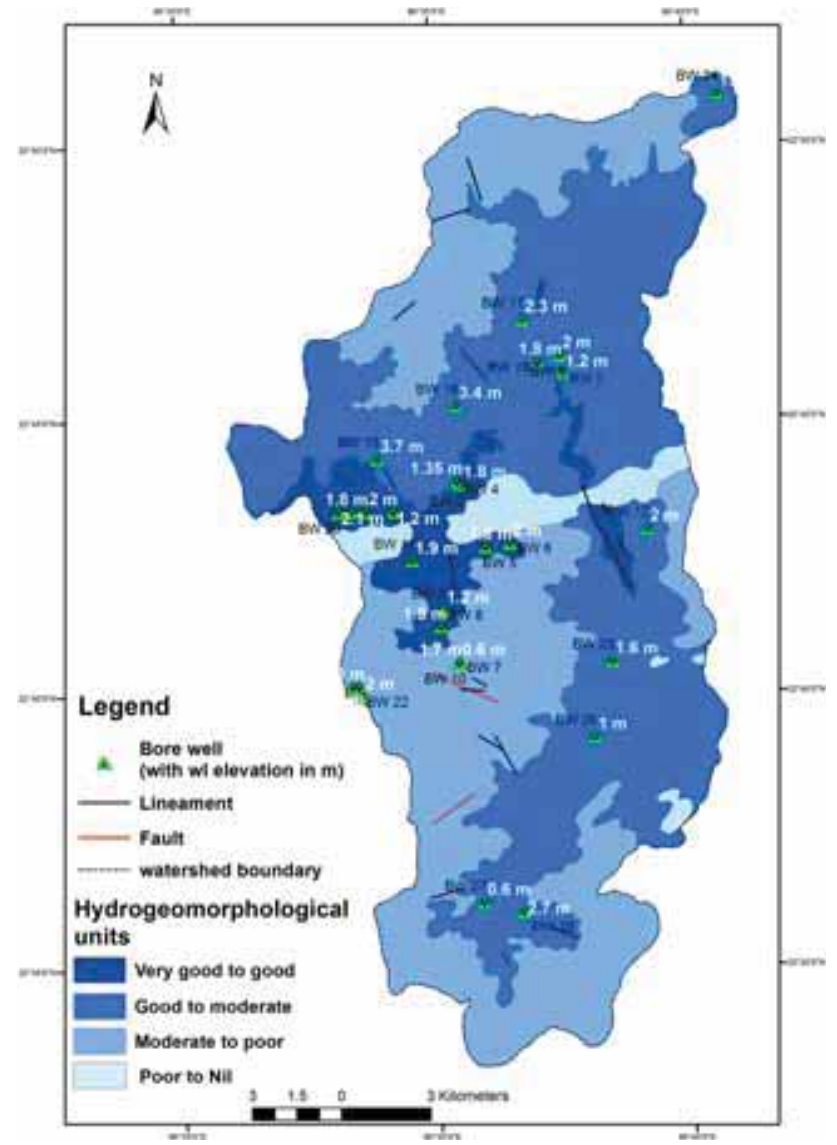

Figure 5. Hydrogeomorphological map.

\section{Spatial and temporal distribution of fluoride}

The geomorphology, hydrogeology and geochemistry of sediments influence the occurrence, origin and mobilisation, as the geogenic contamination in groundwater is closely related to geomorphology. Confined aquifer and unconfined aquifer location were superimposed on the geomorphological map (figure 3).

Six types of geomorphological units have been identified in the study area, i.e., alluvial and point bar exist as loose and unconsolidated with a flat nature and have 0-5\% slope. The largest unit with $46.91 \%$ covers a total of $325 \mathrm{~km}^{2}$ of geographical area identified as pediplain has moderate to strong with $5-15 \%$ slope, the second largest unit is the denudational hill with $15-35 \%$ slope, covering $45.00 \%$ of the total geographical area, mesa and butte is the smallest unit, covering $1.35 \%$ of the total area with $>35 \%$ very steep slope.

These are the valleys filled with unconsolidated alluvial/fluvial material and form zones of good groundwater prospects. The background is formed 


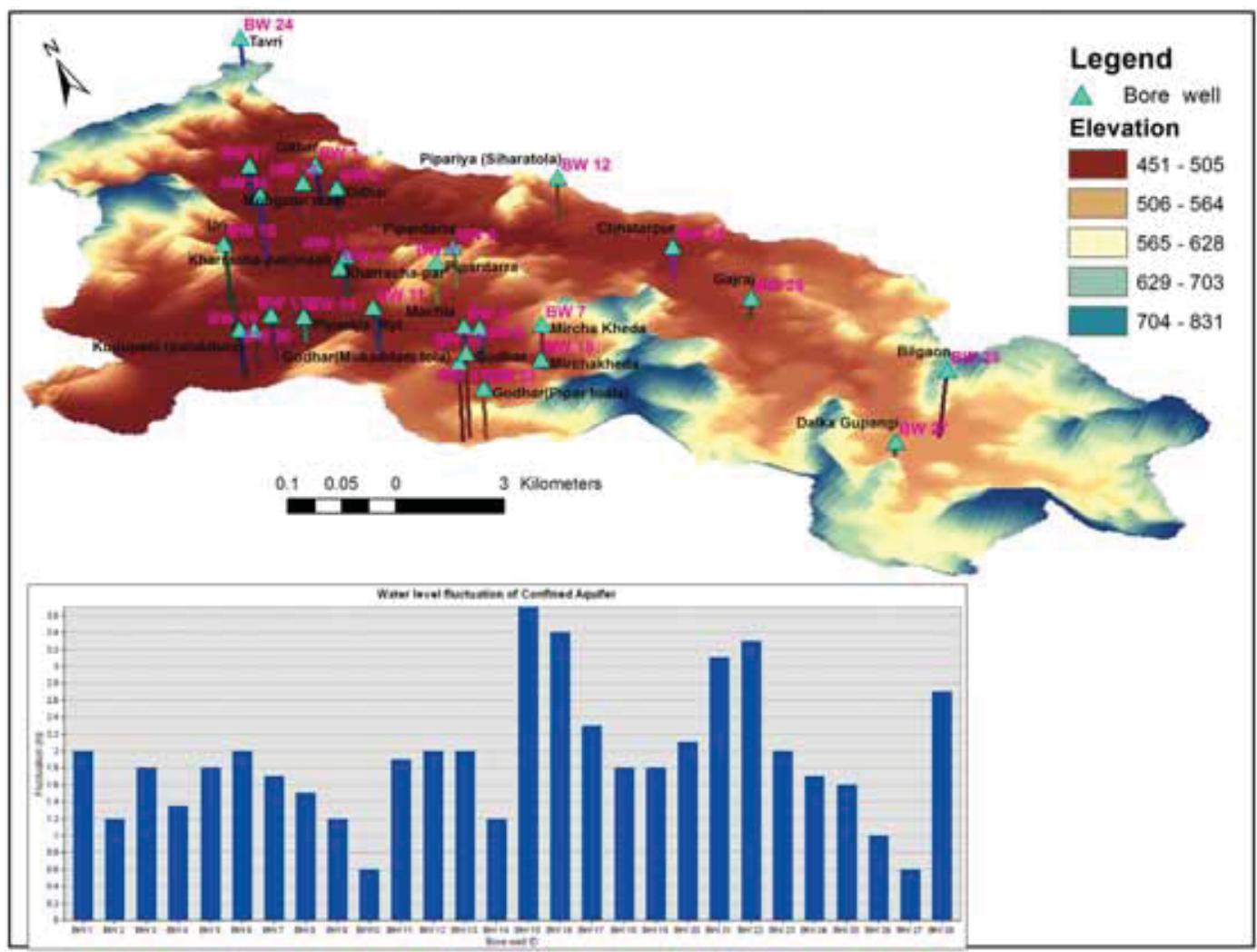

Figure 6. 3D view of water table elevation map and groundwater table of a confined aquifer.

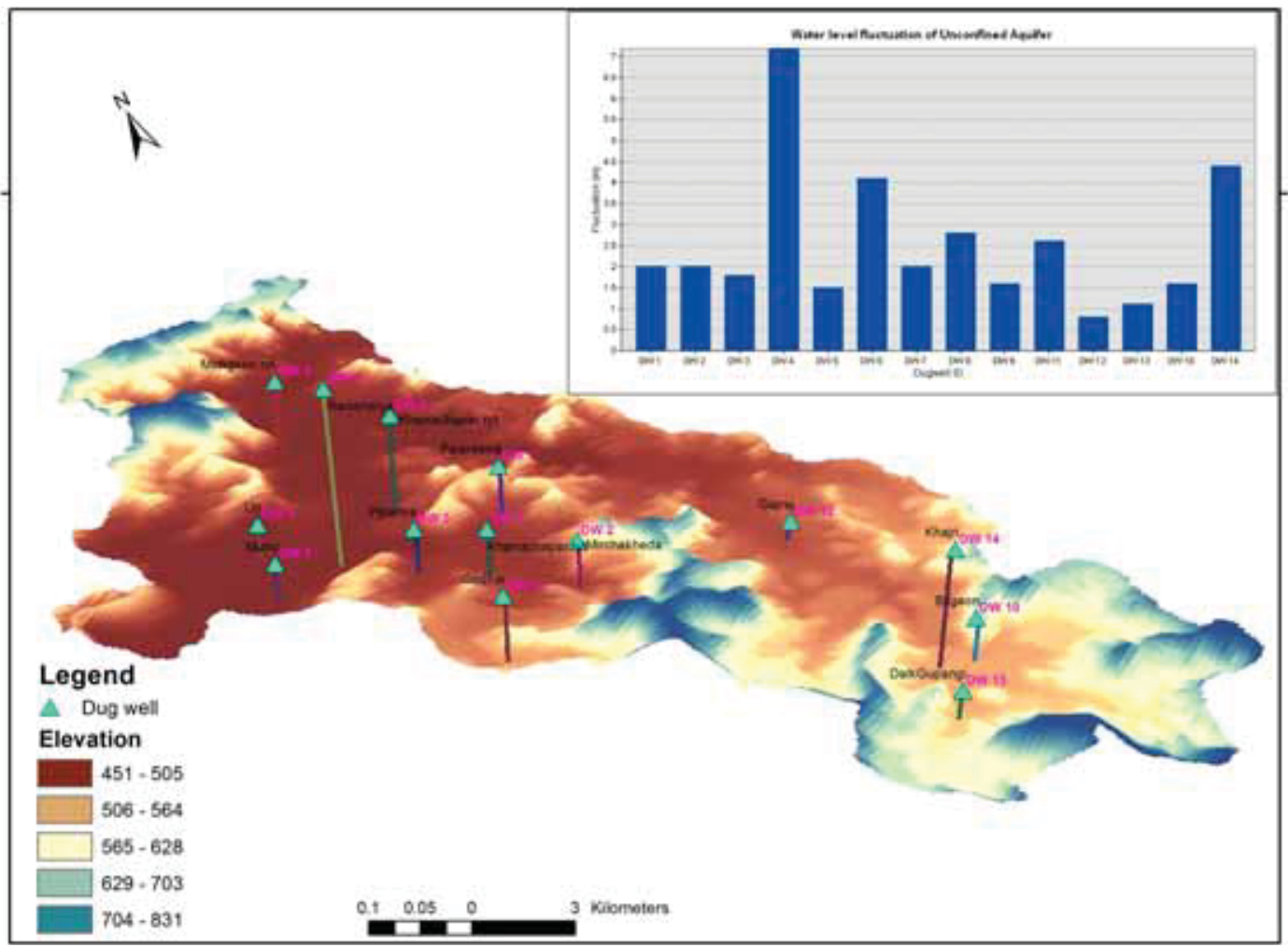

Figure 7. 3D view of water table elevation map and groundwater table of an unconfined aquifer. 


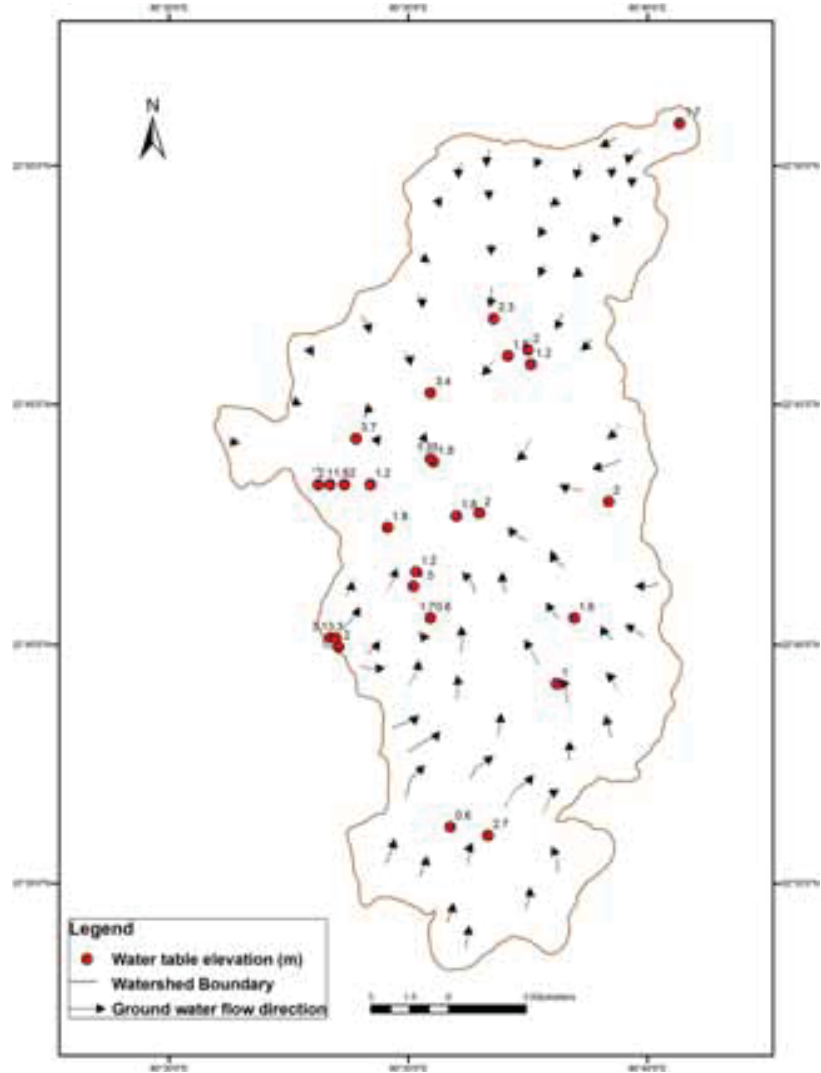

Figure 8. Water table elevation map and groundwater flow of a confined aquifer.

of pediplains made up of granitic gneisses of the Chota Nagpur gneissic complex.

In the groundwater studies, fluoride distribution plays an important role, especially in the demarcation of hydrogeomorphic units and associated groundwater characteristics (Manual for National Geomorphological and Lineament Mapping 2010).

The groundwater flows towards the western direction, and the water table follows to the general topography of the area (figure 8). The fluoride concentration in the study area seems to be controlled by geomorphic units due to the selective capability of different geomorphic units to allow the percolation of water below the ground. In the denudational hill unit, fluoride concentration in the confined aquifer ranges from 0.01 to $10.1 \mathrm{mg} / \mathrm{l}$. In alluvial plains, it varies from 0.54 to $14.64 \mathrm{mg} / \mathrm{l}$ and in the pediplain geomorphic unit ranges between 0.11 and $2.5 \mathrm{mg} / \mathrm{l}$. Majority of the samples show more fluoride concentration in drinking water than the permissible limit $(1.5 \mathrm{mg} / \mathrm{l})$ in the confined aquifer which falls in the alluvial terrain including a conned aquifer having the highest concentration $(14.6 \mathrm{mg} / \mathrm{l})$ located at the Ramkhiriya Shikaritola village, which is located in the western part of the
Table 4. Saturation index values of fluorite and calcite $\left(\mathrm{CaCO}_{3}\right)$.

\begin{tabular}{|c|c|c|}
\hline Village & SI (fluoride) & SI (calcite) \\
\hline Githar & -2.41 & -0.47 \\
\hline Githar & -2.48 & -0.95 \\
\hline Kharrachapar & -2.2 & -0.9 \\
\hline Kharrachapar (Maal) & -2.29 & -0.35 \\
\hline Pipardarra & -1.09 & -0.61 \\
\hline Pipardarra & -1.75 & -4.6 \\
\hline Mirchakheda & -2.9 & -0.36 \\
\hline Machla & -3.59 & -0.26 \\
\hline Machla & -2.45 & 0.11 \\
\hline Mirchakheda & -1.6 & -1.2 \\
\hline Pipariya Ryt & -1.1 & 0.36 \\
\hline Pipariya (Siharatola) & -2.3 & -0.95 \\
\hline Ramkhiriya & -2.6 & -0.66 \\
\hline Ramkhiriya (Shikaritola) & -0.67 & -0.22 \\
\hline Uri & -2.05 & 0.86 \\
\hline Indra Ryt (Khurritola) & -0.16 & -1.3 \\
\hline Mohgaon Ryt & -1.5 & -0.92 \\
\hline Mohgaonmaal & -2.8 & -0.45 \\
\hline Munu & -2.73 & -0.82 \\
\hline Kudupani (Pandatola) & 1.96 & -1.1 \\
\hline Godhar (Mukaddamtola) & -0.78 & -1 \\
\hline Godhar & -1.03 & -1.1 \\
\hline Godhar (Pipartoala) & -2.52 & -1.2 \\
\hline Tavri & -1.88 & -0.97 \\
\hline Chhatarpur & -2.06 & -0.8 \\
\hline Gajraj & -3.04 & 0.16 \\
\hline Dalka Gupangi & -3.61 & 0.58 \\
\hline Bilgaon & -2.53 & -1.6 \\
\hline
\end{tabular}

Unconfined aquifer

\begin{tabular}{lcc}
\hline Village & SI (fluoride) & SI (saturation) \\
\hline Pipardarra & -1.28 & -1.1 \\
Mirchakheda & 0.79 & -1 \\
Pipariya & -0.27 & -0.95 \\
Ramkhiriya & -0.38 & -1 \\
Uri & 0.64 & -1.5 \\
Kharrachapar Ryt & -0.84 & -1.4 \\
Kharrachapar Ryt & -0.35 & -1 \\
Mohgaon Ryt & 0.98 & -1.4 \\
Munu & -1.23 & -1 \\
Bilgaon & -1.67 & -2 \\
Godhar & -0.88 & -1.3 \\
Gajraj & -0.22 & -0.49 \\
Dalk Gupangi & -0.14 & -0.71 \\
Khajri & 1.31 & -1.1
\end{tabular}

watershed, whereas in the case of the unconfined aquifer, the denudation hill has $0.03-0.36 \mathrm{mg} / \mathrm{l}$ and the pediplain has $0.06-0.13 \mathrm{mg} / \mathrm{l}$ and $0.01-0.35 \mathrm{mg} / \mathrm{l}$ in the alluvial plain (figure 3 ). 
Correlation analysis of lithology of the area and the confined aquifer fluoride concentration reveals that the highest value of fluoride $(14.6 \mathrm{mg} / \mathrm{l})$ is found in simple to compound pahoehoe basaltic lava flows and other higher concentration is also found in the same type of lava flow which indicates that this unit contains fluoride-bearing minerals major lineament in the middle of the study area (figure 4).

To evaluate which particular minerals, of the mentioned minerals, might be contributing to the fluoride levels in the groundwater of this area, the use of the geochemical model PHREEQC 3.4.0 was made. The model helps to speciate the quantitative chemical analysis results. Simulations done over the raw quantitative data lead to results presenting phases (major minerals) predicted to be present in the water and saturation index (SI) of these phases.

The SI values obtained from PHREEQC simulations carried out on two sets of data for confined aquifer and unconfined aquifer water samples, one where highest value of fluoride has been recorded and another where the lowest value of fluoride has been recorded, are presented in table 4 .

Fluoride ion takes a relatively long time to leach out into groundwater due to its low solubility. Under such conditions, its occurrence is predominantly controlled by free calcium ions $\left(\mathrm{Ca}^{2+}\right)$ sourced into groundwater majorly from the common mineral, calcite $\left(\mathrm{CaCO}_{3}\right)$ (Jacks et al. 2005). The dissociation reactions and solubility products of fluorite (equations 1 and 3 ) and calcite (equations 2 and 4) can be demonstrated by the following equations (Handa 1975):

$$
\mathrm{CaCO}_{3}+\mathrm{H}^{+} \leftrightarrow \mathrm{Ca}^{2}+\mathrm{HCO}_{3}^{-},
$$

where the equilibrium constant is

$$
\begin{aligned}
K_{\text {calcite }\left(\mathrm{CaCO}_{3}\right)}(K 1) & =\left[\mathrm{Ca}^{2+}\right]\left[\mathrm{HCO}_{3}^{-}\right] /\left[\mathrm{H}^{+}\right], \\
\mathrm{CaF}_{2} & \leftrightarrow \mathrm{Ca}^{2+}+2 \mathrm{~F}^{-} .
\end{aligned}
$$

Equilibrium constant is

$$
K_{\text {fluorite }}(K)=\left[\mathrm{Ca}^{2+}\right]\left[\mathrm{F}_{2}^{-}\right] .
$$

On coupling the above equations, Handa (1975) formulated equation (5) as follows:

$$
\mathrm{CaCO}_{3}(\mathrm{~s})+\mathrm{H}^{+}+2 \mathrm{~F}^{-}=\mathrm{CaF}_{2}(\mathrm{~S})+\mathrm{HCO}_{3}^{-} .
$$

Equilibrium constant is

$$
K_{\text {calcite-fluoride }}(K 1 / K 2)=\left[\mathrm{HCO}_{3}^{-}\right] /\left[\mathrm{H}^{+}\right]\left[\mathrm{F}^{-}\right]^{2} .
$$

From the above formulations, it can be interpreted that at a homogeneous $\mathrm{pH}$ range (defined by the $\mathrm{H}^{+}$ ion concentration), where water is of the bicarbonate type, fluoride concentration in water tends to rise with a dip in the calcium concentration.

The SI of a chemical compound is calculated using the formula as given below:

$\mathrm{SI}=\log _{10} Q / K$. The SI values are explained based on the standard given by Sreedevi et al. (2006), Al-Amry (2009) and Dey et al. (2011).

\section{Source of fluoride and recommendations}

The uneven distribution of fluoride in space and time is primarily due to the variation in mineral assemblage of rocks, differential fracture system and associated hydrochemical processes (Reddy and Rao 2006).

In basaltic rocks, in general, the source of fluoride is basically apatite (Wedepohl 1972; Nanyaro et al. 1984). The uranyl, fluoride apatite and carbonate fluorapatite (Prasad and Shukla 2014) were identified as fluoride-bearing minerals in the Burhner watershed. In groundwater, it occurs as a result of evapotranspiration along the groundwater flow path from replenished areas to local depressions (High fluoride groundwater in Southern India 1979). We suggest that the drinking water source from the affected area may be met from a shallow unconfined aquifer. Confined aquifer water may be used for other domestic purposes. Local users of water should be educated about the hazards of the consumption of high $\mathrm{F}^{-}$rich water and the use of simple methods of defluoridation. Some important defluoridation techniques (Nalgonda, activated alumina and ion exchange) should be adopted in the area.

\section{Conclusions}

Hydrogeochemistry interconnected to the weathering of rocks is responsible for major ion chemistry of groundwater in the Burhner watershed. Waterrock interaction and evapotranspiration, which were further influenced by arid to semi-arid climatic factors of the area, play a key role in the modification of the concentration of species in groundwater, especially, fluoride. The structural variation and intense weathering processes together with a fractured confined aquifer system have forced the release of fluoride from rocks to groundwater in an alkaline environment. If the calcium concentration is high in groundwater in any area, there is a 
possibility of a high concentration of fluoride, whereas it is a direct contrast in the case of sodium. According to SI values, most of the water samples of (confined aquifers and unconfined aquifers) the study area are under-saturated with respect to fluorite and supersaturated with respect to calcite $\left(\mathrm{CaCO}_{3}\right)$.

\section{References}

Agrawal V, Vaish A K and Vaish P 1997 Groundwater quality: Focus on fluoride and fluorosis in Rajasthan; Curr. Sci. 73(9) 743-746.

Al-amry A S 2009 Hydrogeochemistry and origin of fluoride in groundwater of Hidhran \& Alburayhi Basin, northwest Taiz city, Yemen; Delta J. Sci. 33 10-20.

Apambire W B, Boyle D R and Michel F A 1997 Geochemistry, genesis, and health implications of fluoriferous groundwater in the upper regions of Ghana; Env. Geol. 33 13-24.

Bhattacharya P, Chatterjee D and Jacks G 1997 Occurrence of arsenic-contaminated groundwater in alluvial aquifers from Delta Plain, Eastern India: Options for a safe drinking water supply; Water Resour. Dev. 13 79-92.

Chouhan A, Mishra N and Soni Kapil K 2008 Assessment of fluoride in drinking water of fluorosis endemic areas of Mandla, M. P.; Asian J. Animal Sci. 3(2) 219-221.

Chunli S, Wang Y, Xie X and Zhu Y 2015 An isotope hydrochemical approach to understand fluoride release into groundwaters of the Datong Basin, Northern China; Env. Sci. Processes Impacts 17 791-801.

Das B, Talukdar J, Sarma S, Gohain B, Dutta R K, Das H B and Das S C 2003 Fluoride and other inorganic constituents in groundwater of Guwahati, Assam, India; Curr. Sci. 85 $657-661$.

Deshmukh A N, Wadaska P M and Malpe D B 1995 Fluorine in environment: A review article; Geol. Mag. 9 1-20.

Dey R K, Swain S K, Mishra S, Sharma P, Patnaik T, Singh V K, Dehury B N, Jha U and Patel R K 2011 Hydrogeochemical processes controlling the high fluoride concentration in ground-water: A case study at the Boden block area, Orissa, India; Env. Monit. Assess. 184(5) 3279-3291.

District Resources Map (DRM) of Mandla 2003, Geological Society of India.

Farooqi A, Masuda H and Firdous N 2007 Toxic fluoride and arsenic contaminated groundwater in the Lahore and Kasur districts, Punjab, Pakistan and possible contaminant sources; Env. Pollut. 145 839-849.

Genxu W and Guodong C 2001 Fluoride distribution in water and the governing factors of environment in arid north-west China; J. Arid Env. 49 601-614.

Handa B K 1975 Geochemistry and genesis of fluoride-containing ground waters in India; Ground Water 13 275-281.

Hem J D 1991 Study and interpretation of the chemical characteristics of natural water; United States Geological Survey Water Supply Paper 2254, Scientific Publishers, Jodhpur, 3rd edn, pp. 120; 130.

Hounslow A W 1995 Water quality data: Analysis and interpretation; CRC Press, Lewis Publishers, Boca Raton, 54p.
Jacks G, Rajagopalan K, Alveteg T and Jonsson M 1993 Genesis of high F groundwaters, southern India; Appl. Geochem. 8 241-244.

Jacks G, Bhattacharyya P, Chaudhary V and Singh K P 2005 Controlson the genesis of high-fluoride groundwaters in India; Appl. Geochem. 20 221-228.

Kinniburgh D G and Smedley P L 2001 As contamination of groundwater in Bangladesh; British Geological Survey Report, WC/00/19, Dhaka.

Kotecha P V, Patel S V, Bhalani K D, Shah D, Shah V S and Mehta K G 2012 Prevalence of dental fluorosis \& dental caries in association with high levels of drinking water fluoride content in a district of Gujarat, India; Indian J. Med. Res. 135 873-877.

Kundu N, Panigrahi M K, Tripathy S, Munshi S, Powell M A and Hart B R 2001 Geochemical appraisal of fluoride contamination of groundwater in the Nayagarh district, Orissa; Env. Geol. 41 451-460.

Liu Y and Zhu W H 1991 Environmental characteristics of regional groundwater in relation to fluoride poisoning in North China; Env. Geol. Water S 18 3-10.

Muralidharan D, Nair A P and Sathyanarayana U 2002 Fluoride in shallow aquifers in Rajgarh Tehsil of Churu District, Rajasthan, an arid environment; Curr. Sci. 83 699-702.

Nanyaro J T, Aswathanarayana U and Mungure J S 1984 A geochemical model for the abnormal fluoride concentration in waters in parts of northern Tanzania; J. Afr. Earth Sci. 2 $129-140$

Nordstrom D K and Jenne E A 1977 Fluorite solubility equilibria in selected geothermal waters; Geochim. Cosmochim. Acta 41 175-188.

Park K 2011 Park's text book of preventive and social medicine (21st edn); Banarasidas Bhanot Publishers, 1167, Premnagar, Jabalpur, India, p. 577.

Passmore R, Nicol B M, Rao M N, Beaton G H and Demayer E M 1974 Hand book on human nutritional requirements; Monogr. Ser. World Health Org. 61 1-66.

Prasad K and Shukla J P 2014 Identification of source of fluoride contamination in Basaltic terrain; Int. J. Remote Sens. Geosci. 3(2) 40-43.

Pujari P R and Deshpande V 2005 Source apportionment of groundwater pollution around landfill site in Nagpur, India; Env. Monit. Assess. 111 43-54.

Purnima B 2013 Fluoride content distribution in the underground water of Central India Madhya Pradesh; Eng. Tech. India 4(2) 36-39.

Ramesam V and Rajagopalan K 1985 Fluoride ingestion into the natural waters of hard-rock areas peninsular India; J. Geol. Soc. India 26 125-132.

Rao R 1993 Fluorine distribution in waters of Nalgonda district, Andhra Pradesh, India; Env. Geol. 21 84-89.

Rao Subba N 2003 Groundwater quality: Focus on fluoride concentration in rural parts of Guntur district, Andhra Pradesh, India; Health Service J. 8(5) 835-847.

Ravenscroft P, McArthur J M and Hoque B A 2001 Geochemical and palaeohydrological controls on pollution of groundwater by arsenic; In: Calderon 4th international conference on arsenic exposure and health effects (eds) W R Chappell, C O and Abernathy R L, Elsevier, Oxford, pp. 53-77.

Reddy A G S and Rao P N 2006 Occurrence, behavior and genesis of fluoride in groundwater of Wailpalli Watershed in 
Nalgonda District, Andhra Pradesh, India; J. Appl. Geochem. 8 618-630.

Report: District Resource Map of Mandla 2003 Geological Survey of India (GSI).

Report: High fluoride groundwater in Southern India 1979 CGWB, Coimbatore, India.

Report: Standard methods for the examination of water and wastewater 1998 American Public Health Association, Washington DC, 20th edn, pp. 10-161.

Report: Standard methods for the examination of water for drinking water specification IS: 105002003 Bureau of Indian Standards, New Delhi.

Saxena V K and Ahmed S 2001 Dissolution of fluoride in groundwater: A water-rock interaction study; Env. Geol. 40 1084-1087.

Saxena V K and Ahmed S 2003 Inferring the chemical parameters for the dissolution of fluoride in groundwater; Env. Geol. 43 731-736.

Shortt H E, McRobert G R, Barnard T W and Mannadinayar A S 1937 Endemic fluorosis in Madras Presidency; Indian J. Med. Res. 25 553-561.

Singha R P, Singh N, Shashtri S and Mukherjee S 2014 Utilisation of satellite data in identification of geomorphic landform and its role in arsenic release in groundwater; ISPRS Annals of the Photogrammetry, Remote Sensing and Spatial Information Sciences, Vol. II-8, 2014.

Smedley P L, Nicolli H B, Macdonald D M J, Barros A J and Tullio J O 2002 Hydrogeochemistry of arsenic and other inorganic constituents in groundwaters from La Pampa, Argentina; Appl. Geochem. 17 259-284.
Sreedevi P D, Ahmed S, Made B, Ledoux E and Gandolfi J M 2006 Association of hydrogeological factors in temporal variations of fluoride concentration in a crystalline aquifer in India; Env. Geol. 50 1-11.

Srinivasamoorthy K, Chidambaram S, Prasanna M V, Vasanthavihar J P and Anandhan P 2008 Identification of major sources controlling groundwater chemistry from a hard rock terrain - A case study from Mettur taluk, Salem district, Tamilnadu; J. Earth Syst. Sci. 117(1) 49-58.

Subba Rao N, Subba Rao N, Krishna Rao G and John Devadas D 1998 Variation of fluoride in groundwaters of crystalline terrain; J. Env. Hydrol. 6 1-5.

Technical Report 2013 Groundwater exploration in Maharashtra and Union Territory of Dadra Nagar and Haveli; Report, CGWB, Ministry of Water Resources, Govt. of India, pp. 44-46.

Technical Report 1999 High fluoride groundwater in India, occurrences, genesis and remedies; Report, CGWB, Ministry of Water Resources, Govt. of India.

Teotia S P and Teotia M 1984 Endemic fluorosis in India: A challenging national health problem; J. Assoc. Phys. India 32(4) 347-352.

Wedepohl K H 1972 Zinc behavior during weathering and rock alteration; In: Handbook of geochemistry; Vol. II-3, Springer Verlag, Berlin, Germany, pp. 72-80.

WHO Guidelines for Drinking Water Quality 1984 World Health Organization, Geneva, Vol. 2.

Wodeyar B K and Srinivasan G 1996 Occurrence of fluoride in the groundwaters and its impact in Peddavankahalla basin, Bellary district, Karnataka - A preliminary study; Curr. Sci. 70 71-74. 